\title{
MAGNETIC FIELD NORMALIZATION IN RESIDENTIAL BUILDING LOCATED NEAR OVERHEAD LINE BY GRID SHIELD
}

This paper deals with the magnetic field mitigation of $110 \mathrm{kV}$ trefoil single-circuit and double-circuit overhead lines by grid shields. The shields under study are made of aluminum conductors connected in parallel. These shields are mounted on the walls of the building. We study the efficiencies of plane and $U$-shaped grid shields as the dependence from the quantity of metal. As the result, we show that the plane grid shield does not supply the required efficiency of magnetic field mitigation in corner areas of the building. At the same time, the $U$-shaped grid shield having equivalent quantity of metal allows to mitigate the magnetic field to the reference level $0.5 \mu T$ in more than $97 \%$ part of the building. References 11, figures 9, tables 4 .

Key words: magnetic field, shielding, overhead line, right-of-way, reference level.

Досліджено можсливість зменшення магнітного поля в жситлових будинках, які знаходяться на границі охоронної зони одноколових повітряних ліній електропередачі із розташуванням проводів у вершинах трикутника та двоколових повітряних ліній електропередачі 110 кВ, поширених в міських електромережах, за допомогою запропонованих авторами тратчастих екранів. Розглянуті екрани виконано з алюмінієвих проводів, з'єднаних паралельно між собою, та встановлено на стіни будинку. Досліджено ефективності плаского та U-подібного тратчастих екранів різної металоємності. Показано, що плаский гратчастий екран не забезпечує достатнього зменшення магнітного поля в кутових областях житлових будинків. У той же час U-подібний тратчастий екран еквівалентної металосмності дозволяе зменшити магнітне поле до гранично допустимого рівня 0,5 мкТл в більш ніз 97 \% приміщень будинку. Запропоновано рекомендації цодо конструктивного виконання тратчастих екранів. Бібл. 11, рис. 9, табл. 4.

Ключові слова: магнітне поле, екранування, повітряна лінія електропередачі, охоронна зона, гранично допустимий рівень.

Исследована возможность уменьщения магнитного поля в жилых домах, которые находятся на границе охранной зоны распространенных в городских электросетях одноцепных воздушных линий электропередачи с расположением проводов в вериинах треугольника и двухцепных воздушных линий электропередачи 110 кВ, при помощи предложенных авторами решетчатых экранов. Рассмотренные экраны выполнены из алюминиевых проводов, соединенных параллельно между собой, и установлены на стены дома. Исследованы эффективности плоского и U-образного решетчатых экранов различной металлоемкости. Показано, что плоский решетчатый экран не обеспечивает достаточного уменьшения магнитного поля в угловых областях жсилых домов. В то жсе время U-образный решетчатый экран эквивалентной металлоемкости позволяет уменьшить магнитное поле до предельно допустимого уровня 0,5 мкТл в более чем 97 \% помещений дома. Предложены рекомендации по конструктивному исполнению рещетчатых экранов. Библ. 11 , рис. 9, табл. 4.

Ключевые слова: магнитное поле, экранирование, воздушная линия электропередачи, охранная зона, предельно допустимый уровень.

Introduction. The $110 \mathrm{kV}$ overhead lines (OHL) crossing residential areas are the main source of the power frequency magnetic field in residential buildings [1]. Long-term exposure of power frequency magnetic field (even when its level is relatively low) negatively affects on human health. This leads to a global trend of tightening of sanitary standards. In Ukraine, the reference level of power frequency magnetic field for residential areas is $0.5 \mu \mathrm{T}$ [2]. However, this norm does not meet for most residential buildings located near OHL, in particular, on borders of their right-of-way (ROW). This is because the size of ROW, regulated in [3], does not take into account modern requirements for the reference level of power frequency magnetic field. Dismantling and transferring OHL or replacing it with an underground cable line requires significant costs. Therefore, it is advisable to mitigate the OHL magnetic field by electromagnetic shields solid electrically conductive plates, installed on the inner or outer surface of the wall. But such solid shields cannot be used on walls with windows.

In $[4,5]$ the mitigation of the magnetic field, created by a single-circuit OHL with a vertical arrangement of conductors, is considered and a new type of electromagnetic shields is proposed: the so-called grid shield, consisting of a set of aluminum conductors connected in par- allel. The main advantage of this shield is that it does not interfere the light propagation.

However, the possibility of using grid shields to mitigate the magnetic field in residential buildings, located on the ROW border of widespread $110 \mathrm{kV}$ trefoil singlecircuit and double-circuit OHL, creating rotating magnetic field, is not studied.

The purpose of this work is to determine the possibility of the magnetic field normalization in residential buildings, located on right-of-ways borders of typical $110 \mathrm{kV}$ trefoil and double-circuit overhead lines, using grid shields and to develop recommendations for shield design.

Geometric sizes of single-circuit OHL and rightof-way. Fig. 1 shows the accepted designations for singlecircuit tower sizes: $a_{1}, a_{2}, a_{3}$ are the shortest distances from the vertical axis of tower symmetry to the suspension points of conductors; $h_{1}, h_{2}$ are their heights. Note, that depending on climatic conditions towers with different vertical spacing between the conductors are used [2]. Also Fig. 1 shows the numbering of conductors of the single-circuit OHL, adopted in this work. We assume that OHL is symmetric and RMS values of conductors currents are equal to each other, i.e. $I_{3}=I_{2}=I_{1}$.

(C) V.S. Grinchenko, K.V. Chunikhin 


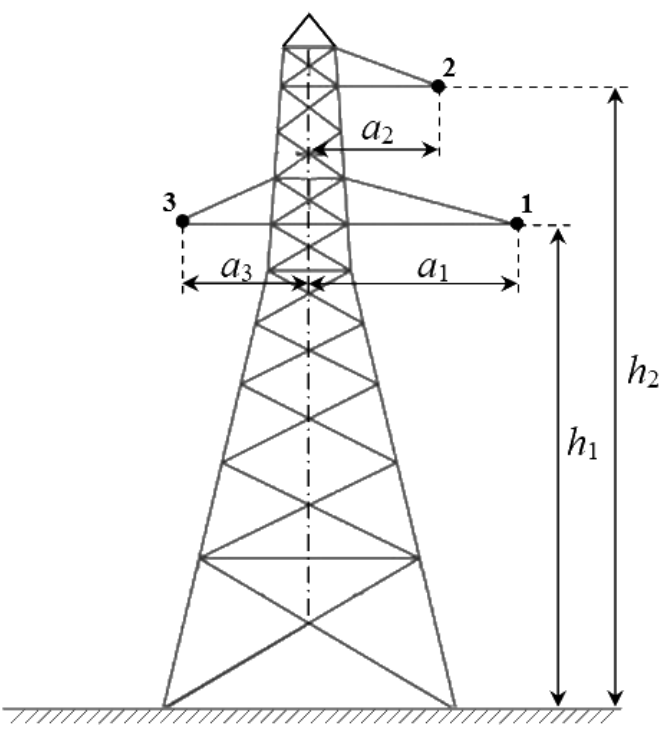

Fig. 1. Schematic representation of $110 \mathrm{kV}$ single-circuit OHL tower

Table 1 summarizes the geometric sizes of typical $110 \mathrm{kV}$ single-circuit towers [6]. We see that $a_{1}, a_{2}, a_{3}$ and $h_{1}, h_{2}$ of P110-3V type tower are the closest to corresponding averaged values, given in Table 1 . Therefore, in further magnetic field calculations for single-circuit $\mathrm{OHL}$ we assume, that $a_{1}=4.2 \mathrm{~m}, h_{1}=19 \mathrm{~m}, a_{2}=2.1 \mathrm{~m}, h_{2}=23 \mathrm{~m}$ and $a_{3}=2.1 \mathrm{~m}$.

ROW is established to create normal operating conditions for electrical networks and ensure their safety, as well as to comply with security requirements. In Ukraine, the ROW size of $110 \mathrm{kV}$ OHL is $20 \mathrm{~m}$ [3]. Therefore, in this work, the distance between the outermost conductor with number 1 and the residential building wall, located along the ROW border $x=0$, is taken to be $20 \mathrm{~m}$ (Fig. 2).

Table 1

Sizes of typical $110 \mathrm{kV}$ single-circuit OHL towers

\begin{tabular}{|c|c|c|c|c|c|}
\hline Tower type & $a_{1}, \mathrm{~m}$ & $a_{3}, \mathrm{~m}$ & $h_{1}, \mathrm{~m}$ & $a_{2}, \mathrm{~m}$ & $h_{2}, \mathrm{~m}$ \\
\hline P110-3V & 4.2 & 2.1 & 19 & 2.1 & 23 \\
\hline P110-3V+4 & 4.2 & 2.1 & 23 & 2.1 & 27 \\
\hline PS110-9V & 4.2 & 2.6 & 19 & 2.6 & 25 \\
\hline PM110-1F & 4.7 & 2.4 & 19 & 2.4 & 23 \\
\hline PM110-3F & 3.9 & 2.3 & 15 & 2.3 & 19 \\
\hline PB-29 & 2.75 & 2.0 & 13.5 & 2.0 & 17.5 \\
\hline Average value & 4.0 & 2.3 & 18 & 2.3 & 22.4 \\
\hline
\end{tabular}

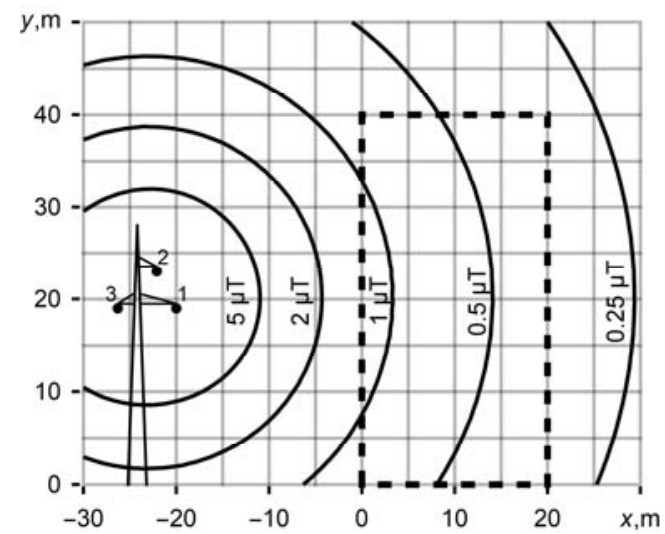

Fig. 2. Distribution of single-circuit OHL magnetic field
Magnetic field of single-circuit OHL. In [7] it is shown that the OHL magnetic field penetrates residential buildings with almost no weakening. To calculate the OHL magnetic field we assume the following $[1,7,8]$ : OHL conductors are infinitely long, parallel to each other and to the ground; the influence of towers on the OHL magnetic field distribution is neglected; the electric currents induced in the ground are neglected, assuming zero electrical conductivity of the soil.

The accepted assumptions allow obtaining an analytical expression for the magnetic field, created by $\mathrm{OHL}$ in free space. According to the first assumption, the magnetic field is plane-parallel. If the Cartesian coordinate system is such as shown in Fig. 2, then the RMS value of the magnetic flux density at an arbitrary point $(x, y)$ can be found using the following expression [7]:

$$
\begin{aligned}
B= & \left(\left|\sum_{p=1}^{3} \frac{\mu_{0} I_{p} e^{j \varphi_{p}}}{2 \pi} \cdot \frac{y-y_{p}}{\left(x-x_{p}\right)^{2}+\left(y-y_{p}\right)^{2}}\right|^{2}+\right. \\
& \left.+\left|\sum_{p=1}^{3} \frac{\mu_{0} I_{p} e^{j \varphi_{p}}}{2 \pi} \cdot \frac{x-x_{p}}{\left(x-x_{p}\right)^{2}+\left(y-y_{p}\right)^{2}}\right|^{2}\right)^{\frac{1}{2}},
\end{aligned}
$$

where $I_{p}$ and $\varphi_{p}$ are the RMS value and the initial phase of the current in the $p$-th OHL conductor; $x_{p}$ and $y_{p}$ are coordinates of the $p$-th OHL conductor in the $x O y$ plane; $\mu_{0}=4 \pi \cdot 10^{-7} \mathrm{H} / \mathrm{m}$ is a vacuum permeability; $j$ is an imaginary unit.

The value of the OHL rated current is taken equal to $I_{1}=500 \mathrm{~A}[1,7,8]$. The initial phases are taken as follows: $\varphi_{1}=-2 \pi / 3, \varphi_{2}=0, \varphi_{3}=2 \pi / 3$. Fig. 2 shows the distribution of magnetic flux density isolines, found using (1). The dotted line marks the contour of the residential building, located near OHL. We see that the magnetic field exceeds the reference level of $0.5 \mu \mathrm{T}$ in the left part of the residential building.

Shielding of single-circuit OHL magnetic field. We select the following parameters of the plane grid shield on the basis of $[4,5]$ : the number of conductors is 81 , the diameter of each conductor is $8 \mathrm{~mm}$, and the distance between adjacent conductors is $0.5 \mathrm{~m}$. The quantity of metal of the shield is denoted by $V$. The shield is located in the plane $x=0$, i.e. on the wall of the residential building facing OHL (Fig. 3). Thus, the coordinates of axes of conductors are as follows: $x_{k}=0, y_{k}=(0.5 \cdot k) \mathrm{m}$, where $k=0 . .80$. The electrical conductivity of the grid shield is equal to $3.5 \cdot 10^{7} \mathrm{~S} / \mathrm{m}$.

To find the shielded magnetic field distribution, we alternately used two different approaches: the numerical simulation within the framework of the model, presented in $[4,5]$, and the analytical calculation within the framework of the model, proposed in [9].

The difference in the magnetic flux density of the shielded field, obtained using these models, lays within $3 \%$. To verify the models, we considered the case of zero conductivity of the shield: the results of the magnetic field calculation at control points agree with the results of the calculation according to the technique from [10]. 


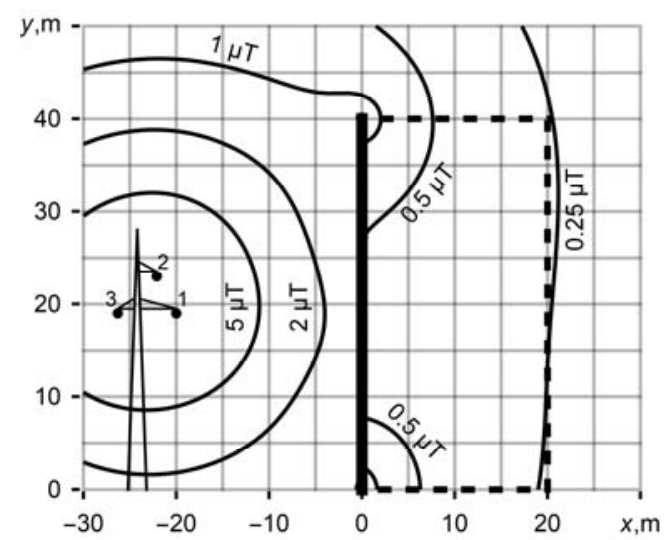

Fig. 3. Distribution of single-circuit OHL magnetic field when using plane grid shield

Fig. 3 shows calculation results of the OHL magnetic field when the plane grid shield is used. We see that the magnetic field does not exceed the reference level of $0.5 \mu \mathrm{T}$ in the bigger part of the residential building. However, the plane shield does not provide a sufficient magnetic field mitigation in corner areas of the building.

To increase the efficiency of shielding, we use the approach proposed in [5], where the usage of U-shaped grid shields is recommended. Consequently, we take the parameters of the U-shaped shield as follows: the number of conductors is 121 , the diameter of each conductor is $6.5 \mathrm{~mm}$, the distance between adjacent conductors is $0.5 \mathrm{~m}$, and the length of arms is $10 \mathrm{~m}$. Fig. 4 shows a U-shaped contour. The conductors are located along this contour with an equal step. The vertical section is identical to the plane grid shield. The arms of the shield (each of them consists of 20 conductors) are located on upper and lower technical floors of the residential building. Axes of conductors of arms have the following coordinates: $x_{k}=(0.5 \cdot k) \mathrm{m}, y_{k}=0$ for the lower arm and $y_{k}=40 \mathrm{~m}$ for the upper arm, where $k=1 . .20$. The quantity of metal of the U-shaped shield under consideration is equal to $V$.

Fig. 4 shows calculation results of the single-circuit OHL magnetic field when the U-shaped grid shield is used. We see that the magnetic field is lower than the reference level in almost the entire residential building. The excess is observed only in the vicinity of the outer conductors of the shield.

We use the magnetic field normalization index $\eta$ as a criterion for the magnetic field shielding efficiency in the residential building. This index determines the percentage of living space, where the magnetic field is normalized and does not exceed the reference level. When the magnetic field is plane-parallel, the normalization index is

$$
\eta=\frac{S}{S_{0}} \cdot 100 \%,
$$

where $S$ is the total of cross-sections of residential building areas, in which the magnetic field does not exceed the reference level, and $S_{0}$ is the cross-section of the entire building. Note that according to [2] the areas closer than $0.5 \mathrm{~m}$ to the walls are not taken into account when finding $S$ and $S_{0}$. Analysis of magnetic field distributions in Fig. 3 and Fig. 4 allows to determine $S$ in each case. The area $S_{0}$ is a product of sides lengths of the shielding region.

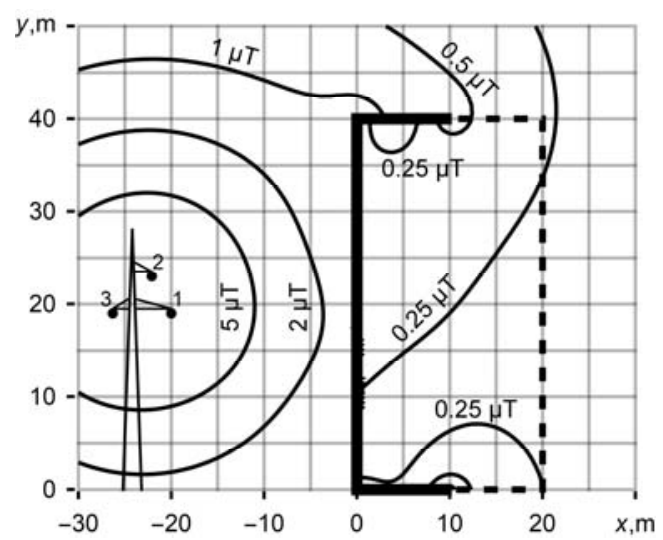

Fig. 4. Distribution of single-circuit OHL magnetic field when using U-shaped grid shield

Then according to (2) the index $\eta$ is $88.3 \%$ when using the plane grid shield and $99.2 \%$ when using the U-shaped grid shield.

An increase or decrease in the quantity of metal of the grid shield, achieved by changing the conductor diameter, leads to a corresponding change in the normalization index. Table 2 shows $\eta$ when varying the quantity of metal of the shield from $0.2 \cdot V$ to $1.2 \cdot V$. Calculation results show that the use of the plane grid shield is ineffective for the trefoil OHL magnetic field mitigation, when the magnetic field is rotating. At the same time, the U-shaped grid shield makes it possible to achieve the normalization index $\eta=97 \%$ at the quantity of metal of $0.5 \cdot V$. Therefore, the conductor diameter can be reduced to $4.6 \mathrm{~mm}$, while maintaining number of conductors of the shield and their arrangement

Note that relatively high values of $\eta$, given in Table 2, also follows from the fact, that in the absence of the shield the magnetic field level does not exceed the reference in the right part of the building. From the analysis of the magnetic field distribution, shown in Fig. 2, it follows that the magnetic field normalization index in the absence of the shield is $38.1 \%$.

Geometric sizes of double-circuit OHL. There are several options for the location of double-circuit OHL conductors on the tower: «vertical arrangement», «straight firtree», «reverse firtree» and «barrel». The last one is the most widespread in Ukraine (Fig. 5).

Table 2

Magnetic field normalization index $\eta$ for residential building located near single-circuit $\mathrm{OHL}$ when using grid shield

\begin{tabular}{|c|c|c|}
\hline \multirow{2}{*}{$\begin{array}{c}\text { Quantity of metal } \\
\text { of shield } \\
\text { referred to } V\end{array}$} & \multicolumn{2}{|c|}{$\eta, \%$} \\
\cline { 2 - 3 } & $\begin{array}{c}\text { Usage of } \\
\text { plane shield }\end{array}$ & $\begin{array}{c}\text { Usage of } \\
\text { U-shaped shield }\end{array}$ \\
\hline 0.2 & 60.5 & 64.3 \\
\hline 0.3 & 68.6 & 81.0 \\
\hline 0.4 & 75.3 & 91.6 \\
\hline 0.5 & 80.1 & 97.4 \\
\hline 0.6 & 83.0 & 99.2 \\
\hline 0.8 & 86.6 & 99.2 \\
\hline 1.0 & 88.3 & 99.2 \\
\hline 1.2 & 89.2 & 99.2 \\
\hline
\end{tabular}




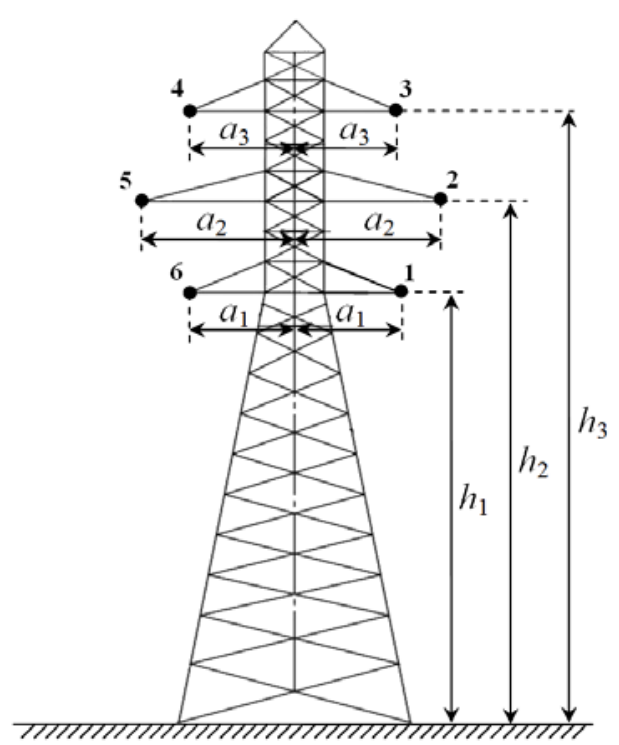

Fig. 5. Schematic representation of $110 \mathrm{kV}$ double-circuit OHL tower

By analogy with previous sections, we introduce the following designations for double-circuit tower sizes: $a_{1}$, $a_{2}, a_{3}$ are the shortest distances from the vertical axis of tower symmetry to the suspension points of conductors; $h_{1}, h_{2}, h_{3}$ are their heights. Also Fig. 5 shows the numbering of conductors of double-circuit OHL. Traditionally to simplify the operation of OHL, conductors 1-3 make up the one three-phase line, and conductors 4-6 form the another one. We assume that both of them are symmetric. Then RMS values of currents in conductors 1-3 are equal to each other, i.e. $I_{3}=I_{2}=I_{1}$. Similarly, for the second line, $I_{4}=I_{5}=I_{6}$. Note that in the general case the values of currents $I_{1}$ and $I_{6}$ can be different.

Table 3 summarizes the geometric sizes of typical $110 \mathrm{kV}$ double-circuit towers [6]. We see that geometric sizes of P110-4V type tower are the closest to average values. Therefore, in further double-circuit OHL magnetic field calculations, we assume $a_{1}=2.1 \mathrm{~m}, h_{1}=19 \mathrm{~m}$, $a_{2}=4.2 \mathrm{~m}, h_{2}=23 \mathrm{~m}, a_{3}=2.1 \mathrm{~m}, h_{3}=27 \mathrm{~m}$.

Table 3

Parameters of typical double-circuit towers of $110 \mathrm{kV} \mathrm{OHL}$

\begin{tabular}{|c|c|c|c|c|c|c|}
\hline Tower type & $a_{1}, \mathrm{~m}$ & $h_{1}, \mathrm{~m}$ & $a_{2}, \mathrm{~m}$ & $h_{2}, \mathrm{~m}$ & $a_{3}, \mathrm{~m}$ & $h_{3}, \mathrm{~m}$ \\
\hline P110-2 & 2.0 & 19 & 4.1 & 23 & 2.0 & 27 \\
\hline P110-4V & 2.1 & 19 & 4.2 & 23 & 2.1 & 27 \\
\hline P110-4V+4 & 2.1 & 23 & 4.2 & 27 & 2.1 & 31 \\
\hline PM110-2F & 2.4 & 19 & 4.7 & 23 & 2.4 & 27 \\
\hline PM110-4F & 2.3 & 15 & 3.9 & 19 & 2.3 & 23 \\
\hline P110-6V & 2.1 & 19 & 4.2 & 25 & 2.1 & 31 \\
\hline P110-6V+4 & 2.1 & 23 & 4.2 & 29 & 2.1 & 35 \\
\hline PS110-10V & 2.6 & 19 & 4.2 & 25 & 2.6 & 31 \\
\hline PM110-8VR & 2.4 & 19 & 3.3 & 25 & 2.4 & 31 \\
\hline PM110-6F & 2.4 & 15 & 3.3 & 21 & 2.4 & 27 \\
\hline Average value & 2.3 & 19 & 4.0 & 24 & 2.3 & 29 \\
\hline
\end{tabular}

Magnetic field of double-circuit OHL. To find the double-circuit OHL magnetic field, we accept assumptions, within the framework of which (1) was obtained. So we use (1), replacing the upper limit of change from 3 to 6 for the counter $p$, to find the double-circuit OHL magnetic field distribution (See Fig. 6 and 7).

It is shown in $[8,11]$ that the double-circuit OHL magnetic field is minimal, when conductors with the same initial phase of currents are arranged centrally symmetrically. Fig. 6 shows the distribution of magnetic flux density isolines when $I_{1}=I_{6}=500 \mathrm{~A}, \varphi_{1}=\varphi_{4}=-2 \pi / 3, \varphi_{2}=\varphi_{5}=0$, $\varphi_{3}=\varphi_{6}=2 \pi / 3$. As before, the dotted line marks the contour of the residential building, located on the ROW border. We see that the magnetic field does not exceed the reference level of $0.5 \mu \mathrm{T}$ in almost all living space, and the magnetic field normalization index is $99.2 \%$.

The highest values of the double-circuit OHL magnetic field are achieved, when the rated current flows $I_{1}=I_{6}=500 \mathrm{~A}$ and the initial phases $\varphi_{1}=\varphi_{6}=-2 \pi / 3, \varphi_{2}=\varphi_{5}=0$, $\varphi_{3}=\varphi_{4}=2 \pi / 3$. In this case, the magnetic field exceeds the reference level of $0.5 \mu \mathrm{T}$ in the entire residential building (See Fig. 7).

Shielding of double-circuit OHL magnetic field. We determine the normalization index $\eta$ for the residential building, located near a double-circuit OHL (Fig. 7), using plane and U-shaped grid shields. Note that the quantity of metal of each shield is $V$.

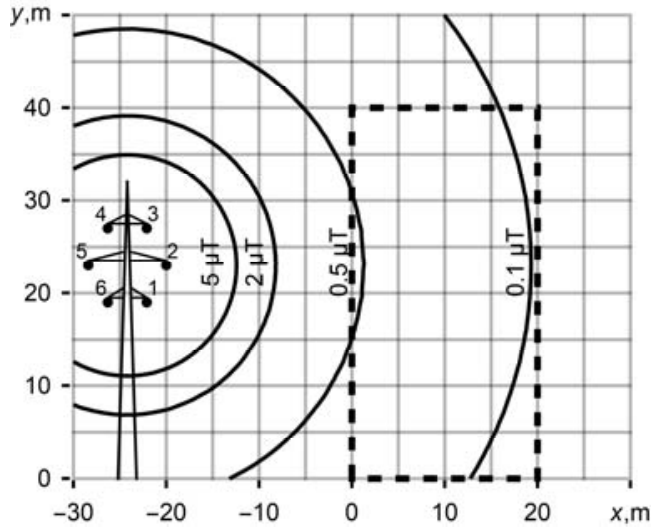

Fig. 6. Distribution of double-circuit OHL magnetic field when $\varphi_{1}=\varphi_{4}, \varphi_{3}=\varphi_{6}$

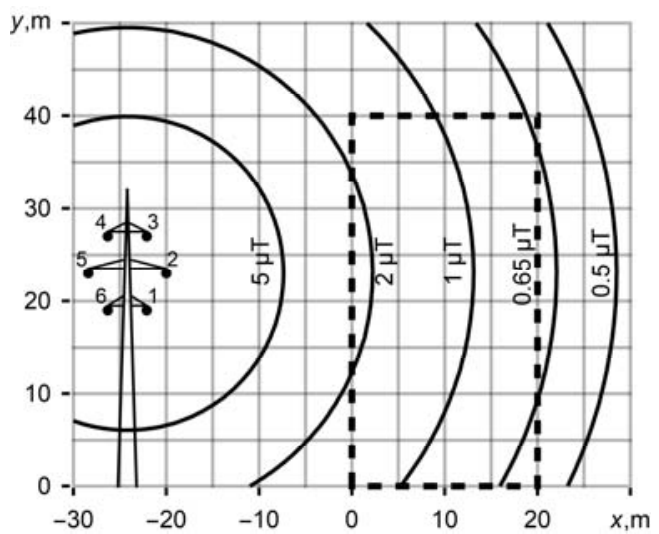

Fig. 7. Distribution of double-circuit OHL magnetic field when $\varphi_{1}=\varphi_{6}, \varphi_{3}=\varphi_{4}$ 
Shields parameters are given in previous sections: the number of conductors is 81 and 121 , respectively, and conductor diameter is $8 \mathrm{~mm}$ and $6.5 \mathrm{~mm}$, respectively. Fig. 8 and Fig. 9 show magnetic flux density isolines when the double-circuit OHL magnetic field is mitigated with the plane and the U-shaped grid shield, respectively.

When using the plane grid shield, the magnetic field does not exceed the reference level of $0.5 \mu \mathrm{T}$ in the bigger part of the residential building. However, as in the case of the single-circuit OHL, the plane shield does not provide the sufficient magnetic field mitigation in corner areas of the residential building. At the same time, the magnetic flux density does not exceed the reference level in almost the entire building, when the U-shaped grid shield is used to mitigate the double-circuit OHL magnetic field.

The analysis of magnetic field distributions, presented in Fig. 8 and Fig. 9, allows determining the normalization index $\eta$. According to (2), it is $83.9 \%$ when using plane shield and $98.7 \%$ when using U-shaped grid shield with quantity of metal $V$.

Table 4 shows $\eta$ when varying the quantity of metal of the shield. We see that it is advisable to use the Ushaped grid shield with the volume of $0.75 \cdot \mathrm{V}$ to mitigate the double-circuit OHL magnetic field. Therefore, the diameter of shield conductors can be reduced to $5.7 \mathrm{~mm}$, while maintaining the number of conductors and their arrangement. In this case, the magnetic field normalization index $\eta$ of the residential building is $97 \%$, which makes it possible to use $97 \%$ of its living space.

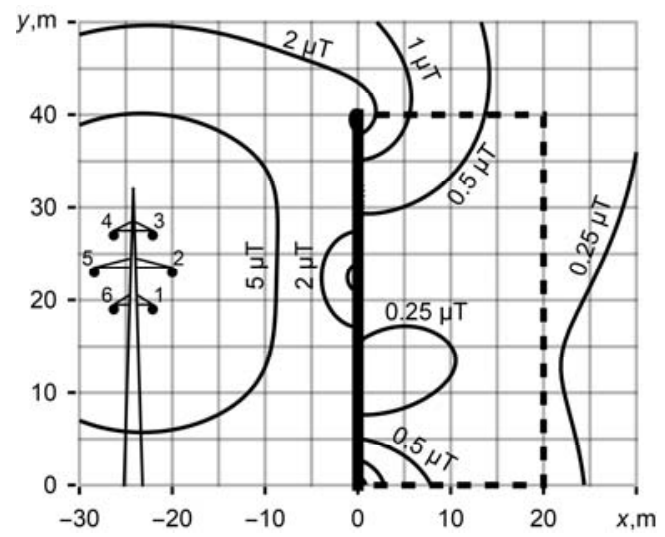

Fig. 8. Distribution of double-circuit OHL magnetic field when using plane grid shield

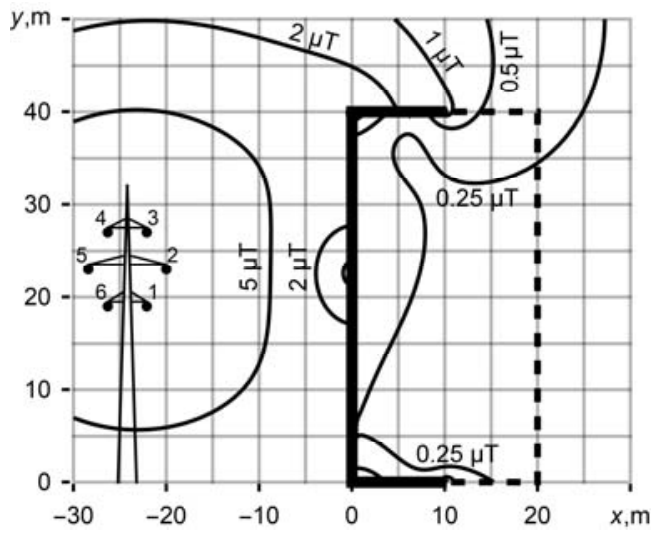

Fig. 9. Distribution of double-circuit OHL magnetic field when using U-shaped grid shield
Table 4

Magnetic field normalization index $\eta$ for residential building located near double-circuit OHL when using grid shield

\begin{tabular}{|c|c|c|}
\hline \multirow{2}{*}{$\begin{array}{c}\text { Quantity of metal } \\
\text { of shield } \\
\text { referred to } V\end{array}$} & \multicolumn{2}{|c|}{$\eta, \%$} \\
\cline { 2 - 3 } & $\begin{array}{c}\text { Usage of } \\
\text { plane shield }\end{array}$ & $\begin{array}{c}\text { Usage of } \\
\text { U-shaped shield }\end{array}$ \\
\hline 0.2 & 15.0 & 27.7 \\
\hline 0.3 & 41.6 & 52.9 \\
\hline 0.4 & 60.7 & 70.6 \\
\hline 0.5 & 69.7 & 82.8 \\
\hline 0.6 & 75.2 & 90.4 \\
\hline 0.75 & 80.3 & 97.0 \\
\hline 0.8 & 81.3 & 97.9 \\
\hline 1.0 & 83.9 & 98.7 \\
\hline 1.2 & 85.2 & 99.0 \\
\hline
\end{tabular}

The obtained results confirm the efficiency of grid shields for the magnetic field normalizing in residential buildings, located on the ROW border of typical $110 \mathrm{kV}$ overhead lines, and allow formulating recommendations for the design of grid shields.

\section{Conclusions.}

1. We show that the plane grid shield made of aluminum $8 \mathrm{~mm}$ diameter conductors and mounted on the wall of the residential building facing $110 \mathrm{kV}$ trefoil single-circuit or double-circuit overhead line mitigates the magnetic field to the reference level of $0.5 \mu \mathrm{T}$ in the bigger part of the living space.

2 . To normalize the magnetic field in the entire residential building located on the border of the right-of-way of $110 \mathrm{kV}$ overhead line, it is advisable to use the U-shaped grid shield.

3. The efficient usage of the grid shield is achieved, when the distance between its adjacent conductors is less than $0.5 \mathrm{~m}$, and the conductor diameter is at least $4.6 \mathrm{~mm}$ for $110 \mathrm{kV}$ trefoil OHL magnetic field mitigation and at least $5.7 \mathrm{~mm}$ for $110 \mathrm{kV}$ double-circuit OHL magnetic field mitigation.

\section{REFERENCES}

1. Pelevin D.Ye. The methods of reducing of the magnetic fields of overhead power lines outside security zones. Technical Electrodynamics, 2014, no. 5, pp. 14-16. (Rus).

2. Electrical installation regulations. Kharkiv, Fort Publ., 2017. 760 p. (Ukr).

3. Decree of the Cabinet of Ministries of Ukraine dated March 4, 1997 No. 209 «About the statement of Rules of protection of electric networks», edition on April 5, 2017. (Ukr).

4. Grinchenko V.S. Mitigation of three-phase power line magnetic field by grid electromagnetic shield. Technical Electrodynamics, 2018, no. 4, pp. 29-32. (Ukr). doi: 10.15407/techned2018.04.029.

5. Grinchenko V., Pyrohova U. Mitigation of overhead line magnetic field by U-shaped grid shield. Proc. 2019 IEEE 2nd Ukraine Conference on Electrical and Computer Engineering (UKRCON), Lviv, Ukraine, 2019, pp. 345-348, doi: 10.1109/UKRCON.2019.8879834.

6. Rokotian S., Zelichenko A., Levin L., et al. Typical project 3.407-68/73. Unified steel normal supports of overhead lines 35, 110 and $150 \mathrm{kV}$. Volume 1. Moscow, 1973. $66 \mathrm{p}$. (Rus). 
7. Rozov V., Grinchenko V. Simulation and analysis of power frequency electromagnetic field in buildings closed to overhead lines. Proc. 2017 IEEE First Ukraine Conference on Electrical and Computer Engineering (UKRCON). Kyiv, Ukraine, pp. 500503. doi: 10.1109/UKRCON.2017.8100538.

8. Mazzanti G. Current phase-shift effects in the calculation of magnetic fields generated by double-circuit overhead transmission lines. Proc. IEEE Power Engineering Society General Meeting, 2004, pp. 413-418. doi: 10.1109/PES.2004.1372827.

9. Grinchenko V.S. Development of a semi-analytical model of a grid shield for the magnetic field mitigation of overhead lines. Proc. VII All-Ukrainian Scientific Conf. of Young Scientists «Information Technologies - 2020», pp. 149-151. (Ukr).

10. SOU-N EE 20.179:2008. Calculation of electric and magnetic fields of power lines. Method (with changes). Kyiv, Minenergovugillja Ukrainy Publ., 2016. 37 p. (Ukr).

How to cite this article:

Grinchenko V.S., Chunikhin K.V. Magnetic field normalization in residential building located near overhead line by grid shield. Electrical engineering \& electromechanics, 2020, no. 5, pp. 38-43. doi: 10.20998/2074-272X.2020.5.06.
11. Rozov V.Yu., Reutskyi S.Yu., Pelevin D.Ye., Pyliugina $\mathrm{O} . \mathrm{Yu}$. The magnetic field of power transmission lines and the methods of its mitigation to a safe level. Technical Electrodynamics, 2013, no. 2, pp. 3-9. (Rus).

Received 30.08.2020

\section{V.S. Grinchenko ${ }^{1}$, K.V. Chunikhin ${ }^{1}$}

${ }^{1}$ State Institution "Institute of Technical Problems of Magnetism of the National Academy of Sciences of Ukraine",

19, Industrialna Str., Kharkiv, 61106, Ukraine,

e-mail: vsgrinchenko@gmail.com,kvchunikhin@gmail.com 